\title{
調整力の開発法に関する基礎的研究
}

\author{
広 橋 義敬* 金原勇**
}

（昭和51年 2 月 25日 受付）

\section{A Fundamental Study on the Development of Co-ordination in Children}

\author{
Gikei Hirohashi (Chiba University) \\ Isamu Kinpara (Tokyo University of Education)
}

abstract

The purpose of this study is to clarify the fundamental principles in developing coordination as one of the fundamental resources that are related with the cybernetic systems of man.

For this purpose, 716 seventh grade students were chosen as subjects and several investigations were made which could verify the following hypotheses.

1. From the viewpoint of actual physical activities, co-ordination as one of the physical resources is grasped as a learning ability of motor skills.

2. The quality of co-ordination actually produced is related with several resources that are related with energy output, especially with the degree of muscular strength.

3. In order to develop co-ordination effectively it is advised to experience various kinds of body movements throughout the period of human growth and to learn skillful movements.

According to this investigation, it was clear that one whose co-ordination is superior to the other has more rapid learning ability of motor skills, well developed motor fitness for performance, various kinds of the movements experienced by himself, efficient movements and more desirable enviroments for actual physical activities.

The results of the investigations indicated that these hypotheses are acceptable.

(Gikei Hirohashi, Isamu Kinpara: A Fundamental Study on the Development of Co-ordination in Children, Jap. J. Phys. Educ., Vol. 22, No. 1, May, 1977, pp. 27 36)

\section{I. 楉}

1. 身体資源 (physical resources あるいは行 動体力）の要因の一つとしての調整力のとらえ方 は，現段階では，確立されているとは必ずしも言
えないようである、したがって, 調整力の開発法 さ究明しょ5とする場合には，まず開発のねらい とすべき調整小のとらえ方を明らかにしておく必 要があろ 5 。

行動体力の要因をエネルギー系とサイバネティ

* 千葉大学: $* *$ 東京教育大学 
ックス系に分ける立場”をとると，一般に調整力 は後者に属するものとして位置つけられている。 調整力（co-ordination）は，これまで協応性， ${ }^{2)}$ 声るいは巧緻性の意味に，あるいはより広く平衡 性（balance）や敏しょう性（agility）を含めた 意㕲に，さらに柔軟性 (flexibility) を含めた意 泝 ${ }^{8)}$ にも使われている。体育科学センタ一調整小 话!明委員会では，「調整力とは psychological な 要素含んだ動作を老規定する physical resources

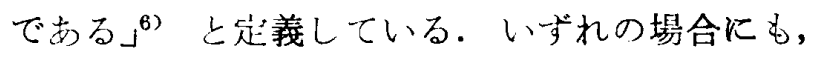
調整少恪種の体育運動，作業などで要求される

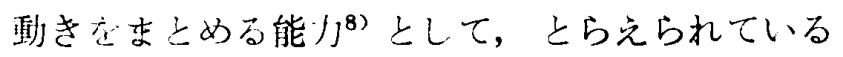
と言光よう。

2.停き走まとめる能力としての調整力は，運 動技術や作業技術之関連つけると，一つには，身 につけている技術（技能あるいはスキル）として 存在している.しかし, 各種の運動技能, 作業技 能などは，身につけ上5とするそれぞれの技術の 学習能力にすぐれていなければ効果的に十分に身 につけるこ上はできないはずである，金原4,5) 行動体力あるいは身体資源の一つとしての調整力 を運動学習上閉連づけて「運動技術の学習能力」 としてとらえている。研究の目的の一つは，身 体資源としての調整力に関するこのよ5なとらえ 方が，体有奏践の立場から，適切であるかどうか 先検討することにある。

3. 各個人の身につ计ている身体資源の一つと しての調整力の水準は，大きく素質的要因と運動 に関する生育史的要因とによって炔まってくると みられる。これまで, 身体運動における調整機能 のメカニズム, ${ }^{1)}$ 各種の測定法にもとづく調整小 の発達過程, ${ }^{3)}$ 運動技能の習熟過程》などに関す る研究が行なわれてきた。しい,これらの研究 では，調整力の開発法に関する原則恣確立できる

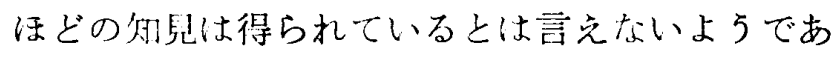
る.

身体資源としての調整打長い生育史を通して しだいに開発されていくために，その占験的実践 による研究はきわ好困難である。本研究の主な 目的は，このような実験に代わるような研究法に よって, 調整力開発法の原则を究明しょ5とする ことにある。

\section{II. 研 究方法}

1. 調整力のとら方, 調整力開発法の原則な どに関連する仮説

次の三つの仮説を設定した。

(1) 身体資源の-Dつとしての調整力は運動技術 の学習能力としてとらえられる.

(2) 奏際の運動を通してとらえられている調整 力の評価には, 行動体力の他の要因, とくに 筋力の䴬劣が大きく影響している.

(3) 身につけている調整力の水準は，薪質のみ でなく，より以上に，運動経験に関する生育 歴に大きく影響される。一般に, 経験した運 動の種類が多い者ほど，また経験した運動に わたって効果的な動きを身につけている者ほ ど調整力にすぐれている。

\section{2. 調查方法}

前述した仮説を検証するための資料を得ようと して次のような諸調查を行なった。

（1）自己評価による質問紙法による第 1 䚾目の 調查 (1971年)

身体資源としての調整力がすでに大きく開発さ れ，その個人差が著しいとみられる中学校 2 年生 を対象に選び，次に例示した 4 種の質問事項にわ たって調查した，調查では,「器用さ」というこ とばを調整力と同義語として用いた。

千葉県の四つの小都市にわたる 4 校の男子 264 名, 女子 272 名について, 体有担当教師が一つ一 つの質問事項を読みあげてから記入させるよ5に して学級単位に調査した。調查期間证1971年 6 月 15日から 7 月 5 日にわたった。

（2）事例史的研究法による第2 吺目の調査 (1972年)

体育・スポーツの場で器用さ（調整力）にとく にすぐれている者と劣っている者とを，教師の評 価，生徒の自己評価などを基礎にして抽出し，次 に列挙する諸項目にわたって，それそれ異なった 方法で調查した。調查対象は，千葉県の四つの小 都市の 4 校にわたる中学 2 年生, 男子 90 名, 女子 90名である.

(1) 運動経験からみた生育歷, 現在の運動生活 
第1回目（1971年）の調查に用いた質問紙

一一質問事項について例示したもの一--

1. 調整力（器用さ）と運動技能

器用さ

・運動するときよくあの人は器用だとか，あるいは不器用だと言います。現在のあなたは，版をだちにくらべ て器用なほうですか, それとも不器用なほうですか.

非常に器用なほろで 器用なほうである。

ある。

普通である。

不器用なほうである。

韭常に不器用なほ うである。

\section{現在の運動技能}

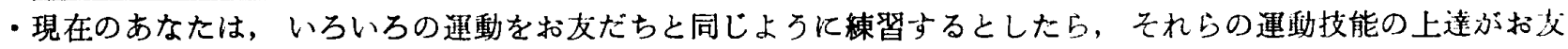

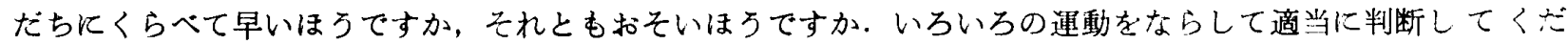
さい.

।

技能の上達が非常に 技能の上達がはやい㨁である。技能の上達が拓そいほ技能の上達が非常に はやいほうである。污である。 うである。 扣ていほうである。

2. 調整力（器用さ）と体格

現在の体位水準

・現在のあなたの身長は，お友だちにくらべて熍いはうですか，て机とも低いはうですか。

I

身長が非常に麗いほ うでらる。

\section{身長が高いほうであ 普通である。} る.
身長が低いほうであ 身瑯が非常に低いは る。 方である。

3. 調整力（器用さ）と体力

現在の体力水準

・現在のあなたは，いろいろの運動やテストなどを通してみて，招交だちにくらべて，力持ちのはうですか（筋 力にすぐれているほうですか)，それとも劣っているほうですか。

\begin{tabular}{|c|c|c|c|c|}
\hline 1 & | & 1 & 1 & \\
\hline 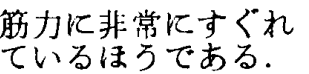 & $\begin{array}{l}\text { 篮力でするぐある. } \\
\text { 方ている }\end{array}$ & 普通 & $\begin{array}{l}\text { 筋力に劣っているほ } \\
\text { 万である. }\end{array}$ & $\begin{array}{l}\text { 筋力に非常に劣って } \\
\text { いるほゔあ。 }\end{array}$ \\
\hline
\end{tabular}

4. 調整力（器朋さ）と運動経験からみた生令㷊

\section{|運動歴}

・あなたは小さいときから今日にいたるまでの間に，自由な時間に運動に親しんだ時間が多かったと思います か，それとも少なかったほうだと思いますか。

小兴校に入る前，小学校 1 年から 3 年まで，小学校 4 年から 6 年生まで，中学校に入ってからの阢つに分け

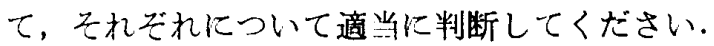

(1) 小学校に入る前

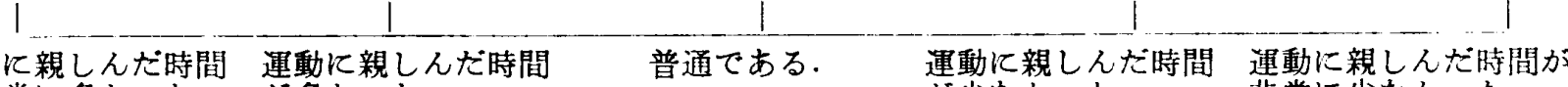

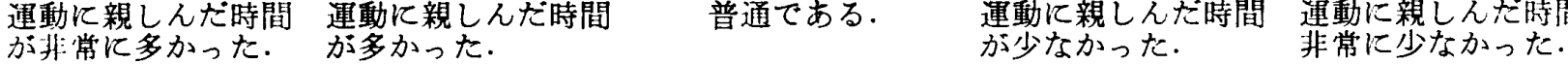

(2) 小学校 $1 \sim 3$ 年

(3) 小学校 $4 \sim 6$ 年

(4) 中学校核入って

備考：このほか, 調整力（器用さ）と運動技能问関しては, 技能習得の可能性, 技能練習中の集中力, 教利体命 時の技能水準などについて, 調整力（器用さ）と体格に関しては，体重について，調整力（器用さ）と体

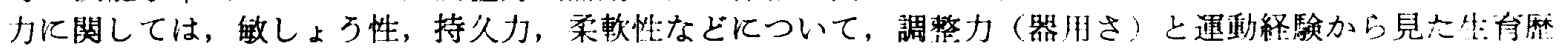
に閣しては，経験した運動の種類について調查した。 
の実態などを，個人別に面接法によって調査 した。

（2) 体格，行動体力，基礎運動能力などを実際 に湘定した。

(3) 家族の運動技能，作業技能などの水準，体 命・スポーツに対する態度（伍值観）などを 質問紙法によって調查した。

(4) 現在の知能, 学力, 健康状態などについて は既成の資料を活用した。

調査は1972年 6 月15日から 7 月15日にわたっ た。

\section{III. 桔果と考寀}

第 1 回目（1971年）の調査結果 [表 1-(1)]は， 調整力（器用さ）についての自己評価法（質問紙 の調查項目 1) にもとついて, 被調查者を 5 段階
に分けて整理したものである，第 2 [1] 目（1972 年）の調査結果〔表 1-(2)〕は, 非常に器用な群 と非常に不器用な群が調査対象になっているの で，2群に分けて整理した。

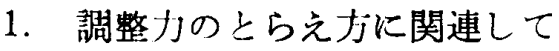

表 1 -(1) は，第 1 国目の調査結果で，生徒の白 己評価による調整力の传劣とけ!己評価による技能 上達の速さ，習得できると思 5 技能水準，技能練 習における集中力の優少，教科体育で教材となっ ている諸種目にわたって身につけている平均的技 能水準などの関係を示したものである。

表 1 -(1) から，器用さ（調整力）にすぐれた群 に属する者は，不器用（調整力に劣る）な群に属 する者にくらべて，器用さにすぐれていると目己 評価している者の率が，いずれの観点からも多い

表 1一（1）調整力（器用さ）の㑩劣と運動技能上達の速さなどとの関係（その1）（中学 2 年，1971年）

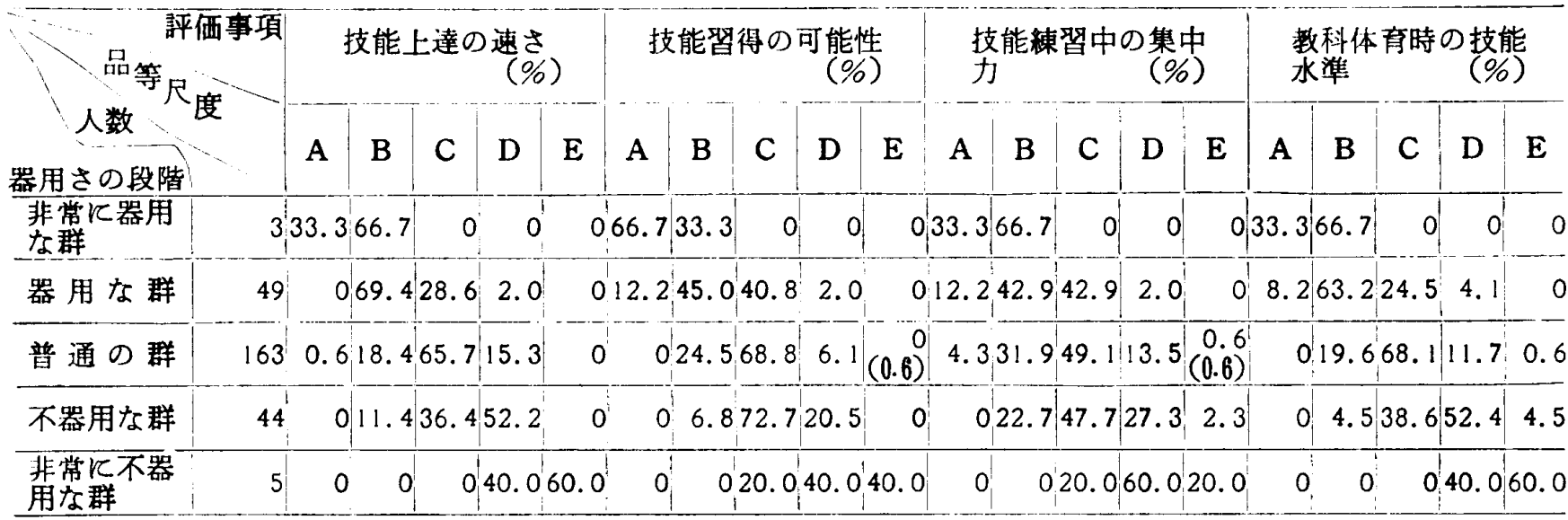

傅考：1. 器用さの段階の各群の数字は，器用さの自己評価汇よる264名中の，それぞれに属する人数（\%)を示す.

2. 品等尺度のAは「非常にすぐれている」，Bは「ずれている」，Cは「普通」，Dは「劣っている」，Eは 「非常飞劣っている」を示す。

3. 表中の（）は，答えのなかった埸合を示す.

表 1一（2） 調整力（器用さ）の優劣と運動技能上達の速さなどとの関係（その 2 ）（中学 2 年, 1972年）

\begin{tabular}{|c|c|c|c|c|c|c|c|c|c|c|c|c|}
\hline \multirow{2}{*}{$\begin{array}{l}\text { 性 } \\
\text { 別 }\end{array}$} & \multirow{2}{*}{$\begin{array}{l}\text { 器用 · 不器 } \\
\text { 用 } の \text { 別 }\end{array}$} & \multirow{2}{*}{$\mid \begin{array}{l}1 \\
\text { 数 }\end{array}$} & \multicolumn{5}{|c|}{ 各種の運動技能習得の速さ（\%) } & \multicolumn{5}{|c|}{ 各種の運動技能水準（\%） } \\
\hline & & & A & B & $\mathrm{C}$ & $\mathrm{D}$ & E & A & B & $\mathrm{C}$ & D & $\mathrm{E}$ \\
\hline \multirow{2}{*}{ 男 } & 器用な群 & 45 & 20 & 60 & 20 & 0 & 0 & 79 & 20 & 11 & 0 & 0 \\
\hline & 不器用な群 & 45 & 0 & 0 & 47 & 33 & 20 & 0 & 0 & 27 & 50 & 23 \\
\hline \multirow{2}{*}{ 女 } & 器用な群 & 45 & 16 & 44 & 40 & 0 & 0 & 50 & 30 & 20 & 0 & 0 \\
\hline & 不器用な群 & 45 & 0 & 0 & 33 & 60 & 7 & 0 & 7 & 26 & 60 & 7 \\
\hline
\end{tabular}

借考 1. A 「非常にすぐれている」，Bは「すぐれている」，Cは「普通」，Dは「劣っている」，Eは「非常に劣 っている」を示す. 
ことがわかる。

表 1 -(2)に心した第 2 回目の調査結果からも， 調整力に非常にすぐれた群と調整力に非常に少る 群との間には，自己評価による，運動技能習得の 速さや身につけている技能水準流どに関して著し い相運のあることがわかる。

上述した二つの調査結果は，行動体力あるいは 身体資源の一つとしての調整力（器用さ）は運動 技術の学習能力としてとらえられることを示する のと言えよう。

2. 調整力とエネルギー系の体力要因などとの 関係について

表 2 は調整力の優劣と体格との関係を示した第 2 回目の調查結果である。この資料から，男子の 不器用な群には, 器用な群にくらべて形態的に小 さい生徒の多いことがわかる，女子では，不器用 な群は身長に打いてわずかに劣る傾向が認められ るにすきない。
表 2 調整力（器用さ）の僧劣と体格との関係

（中学 2 年，1972年）

\begin{tabular}{|c|c|c|c|c|}
\hline 性 & 器用・不器 & 人 & 体 & 格 \\
\hline 別 & 用 の 別 & 数 & $\begin{array}{cc}\begin{array}{r}y^{1} \\
M\end{array} & \begin{array}{c}\text { (S.D } \\
\mathrm{cm}\end{array}\end{array}$ & $\begin{array}{ll}\text { 体 } & \text { (S.D } \\
\mathrm{kg}\end{array}$ \\
\hline 男 & $\begin{array}{l}\text { 器用な群 } \\
\text { 不器用な群 }\end{array}$ & $\begin{array}{l}45 \\
45\end{array}$ & $\begin{array}{l}160.55(6.42) \\
153.72(6.90) !\end{array}$ & $\begin{array}{l}49.7 * \\
45.79(8.10) \\
4.61)\end{array}$ \\
\hline 女 & $\begin{array}{l}\text { 器用な群 } \\
\text { 不器用な群 }\end{array}$ & $\begin{array}{l}45 \\
45\end{array}$ & $\left\{\begin{array}{l}154.07(4.77) \\
151.59(7.17)\end{array}\right.$ & $\begin{array}{l}45.25(5.76) \\
45.97(9.27)\end{array}$ \\
\hline
\end{tabular}

体格についての自己評価による第 1 [回目の調查 結果にも同じような傾问が認められた。

上述した結果は，一般に，身体の形態的発達は 調整力の優劣に関連する要因の一つになるが，重 要な要因となるものでないことをボすもとと言古 上5.

表 3-(1)は調整打優少と行動体力之の関係 䘮，表 3-(2) は調整力の優劣と基礎運動能力との

表 3-（1）調整力（器用さ）の優劣と行動体力との関係（中学 2 年，1972年）

\begin{tabular}{|c|c|c|c|c|c|c|c|c|c|c|}
\hline & 器用・ & 人 & & & 体 & 测 & 定 & 項 & & \\
\hline & 不器用 & & $\begin{array}{c}\text { 反復横とび } \\
\text { (点) }\end{array}$ & 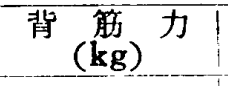 & 挃 $(\mathrm{kg})$ 力 & $\begin{array}{l}\text { 垂 㣀 } \\
\text { (cm }\end{array}$ & n) & $\begin{array}{l}\text { 立位体前屈 } \\
(\mathrm{cm})\end{array}$ & $\begin{array}{c}\text { 上体そ5し } \\
(\mathrm{cm})\end{array}$ & 照台 \\
\hline 别 & の 別 & 数 & $M(S \cdot D)$ & $M(S \cdot D)$ & $M(S \cdot D)$ & M ( & $(S \cdot D)$ & $M(S \cdot D)$ & $M(S \cdot D)$ & $\mathbf{M}$ \\
\hline & $\begin{array}{l}\text { 器用な } \\
\text { 群 }\end{array}$ & 45 & $42.00(3.44)$ & $117^{* * *} 38(30.62)$ & 37.35( & 54.35( & $(5.76)$ & 36) & $54.17(5.36)$ & 67.30( \\
\hline & $\begin{array}{l}\text { 不器用 } \\
\text { な群 }\end{array}$ & 45 & $37.00(4.65)$ & $86.06(27.50)$ & $27.39(5.34)$ & $42.02 C$ & $6.27)$ & $9.79(4.53)$ & $49.40(4.58)$ & 56.24 \\
\hline & $\begin{array}{l}\text { 器用な } \\
\text { 群 }\end{array}$ & 45 & $39.60(2.33)$ & $84.84(20.50)$ & 27.966 & 46.70( & $(4.81)$ & $18.02(4.34)$ & $57.85(4.34)$ & $6 i$ \\
\hline & $\begin{array}{l}\text { 不器用 } \\
\text { な群 }\end{array}$ & i & $34.90(2.88)$ & $57.89(14.21)$ & $24.50(6.27)$ & 34.70( & $6.32)$ & $13.26(6.76)$ & $50.00(6.76)$ & 59.00 \\
\hline
\end{tabular}

表 3一（2）調整力（器用さ）の優劣之基礎運動能力との関係（中㘶: 2 年，1972年）

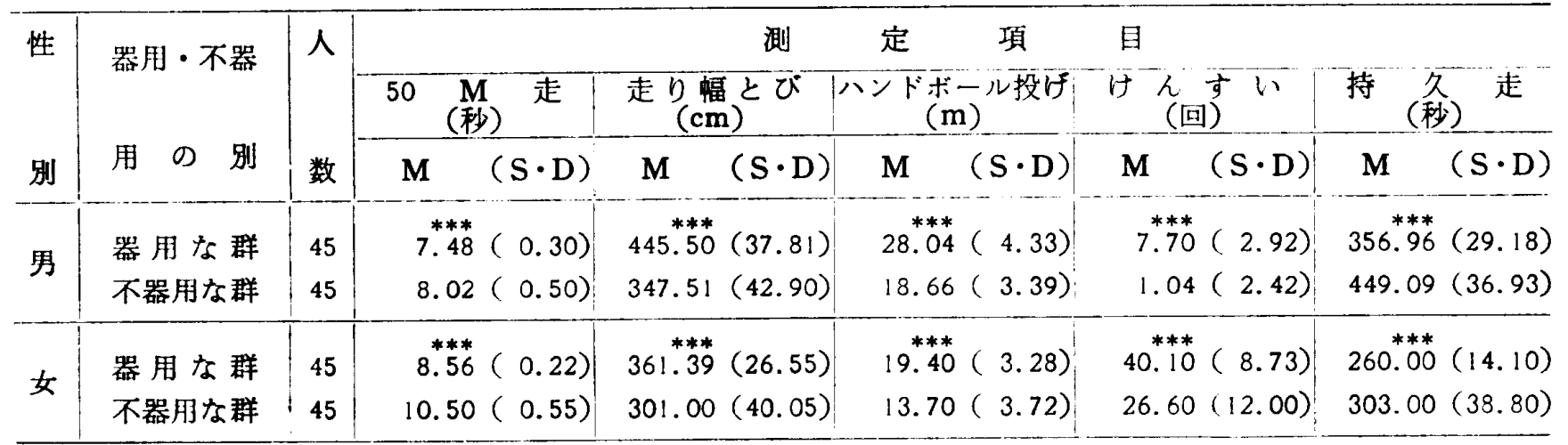

備考: ${ }^{* * *} \mathrm{p}<0.001$ 
関係を示した第 2 [间目の調査結果である。これら の資料から，すべての測定種目にわたって器用的 群がリぐ机ていることがわかるなお拈，背筋力を 体重単位でとらえて比䡆すると，洏舴間には，罗 子では平均して $0.5 \mathrm{~kg}$ ，女子芋では $0.82 \mathrm{~kg}$ の差が 認められた。

行動体力についての山己評価による第 1 们目の 調食に招いても，同じょうな結果が得られた。

ト䢞した諸結果は，調整才はサイバネティック ス系の体少要因として位置づけられるが，尖際の 運動の場でとらえられる調整力の優少には，エネ ルギー系の体力要因としての筋小, パワー, 持久
力なども大きく影響していることを示すものと言 克よ5。

3. 運動に関連する生有歴が調整力の発達に及 ぼす影響について

（1）調整才」の優劣と運動時間，経験した運動の 種類の多少などとの関係

白己評洒による第 1 回目の調查によると，表 4 ー(1)に示すよ5に，調整力にすぐれた器用な群は 不器用な群にくらべて, 一般に幼児期, 巟童期, 青 年前期 (中学校人学後) を通して, 生活の中で運 動に用いてきた時間が多い。また，表 4-(2)に示

表 4一（1）調整力（器用さ）の優劣と運動歴との関係（その1） 一一運動に親しんだ時間——

（中学 2 年男子, 197 !年)

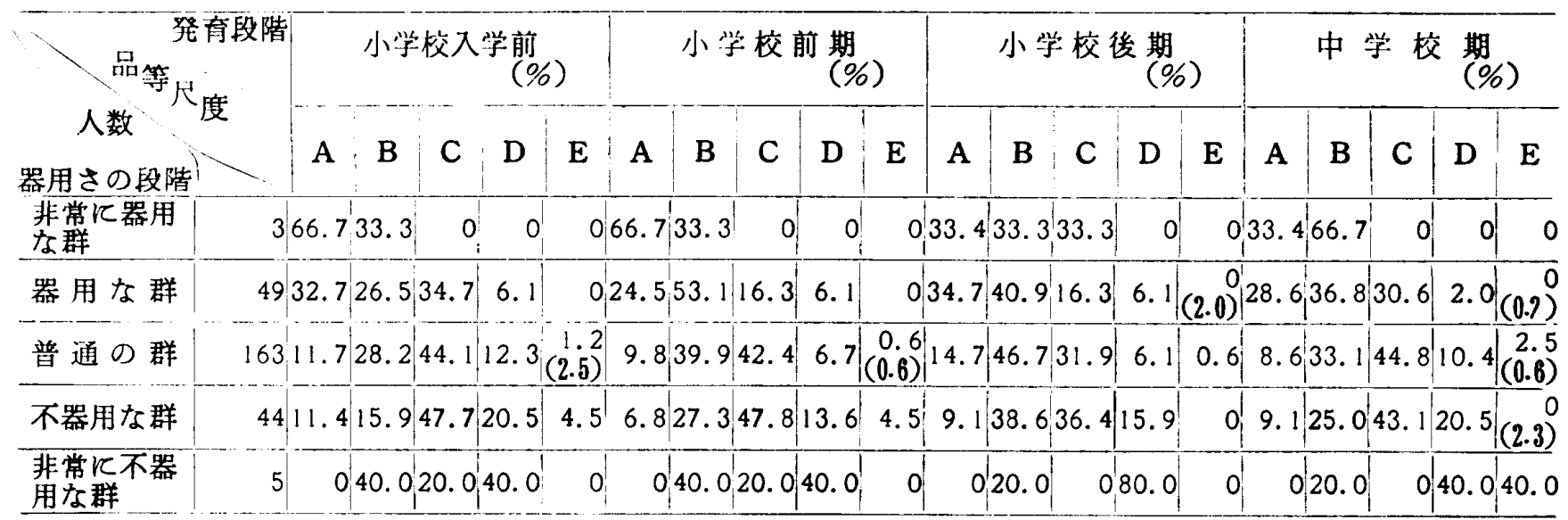

備考：1. 器用さの段階の各群の数字は, 器用さの自己評価による264名中の, それぞれに属する人数（\%)を示す.

2. 品等度のAは「非常に多い」, Bは「多い」, Cは「普通」，Dは「少ない」，Eは「非常に少ない」を示 3. 表中の（）は答えのなかった場合を示す.

表 4-(2) 調整力（器用さ）の優劣と運動歴との関係（その2） ——親しんだ運動の種類——

（中学 2 年男子, 1971年)

\begin{tabular}{|c|c|c|c|c|c|c|c|c|c|c|c|c|c|c|c|c|c|c|c|c|c|}
\hline 品等 & & & 小学 & 校入 & (\% & & & 小当 & 学校 & 前 & & & 小 & 学校 & 後 & & & 中 & 学 极 & 交 期 & 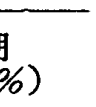 \\
\hline $\begin{array}{l}\text { 人数 } \\
\text { 器用さ } \\
\text { の段階 }\end{array}$ & & A & B & C & $\mathrm{D}$ & $\mathrm{E}$ & A & B & C & D & $\mathrm{E}$ & A & B & C & D & $\mathbf{E}$ & A & B & C & D & $\mathrm{E}$ \\
\hline 韭常飞器 & & 33.3 & 66.7 & 0 & 0 & 0 & & 66.7 & 0 & 33.3 & & 33.4 & 33.3 & 33.3 & 0 & & 33.4 & 33.3 & 33.3 & 0 & 0 \\
\hline 器用な群 & 49 & 12.2 & 30.6 & 40.9 & 6.11 & $(4.1)$ & 6.1 & 36.8 & 30.6 . & 6.1 & $\begin{array}{r}2.0 \\
(18.1)\end{array}$ & 2. 2 & 38. 8 & 28.6 & 4.1 & $\begin{array}{r}2.0 \\
(14.3)\end{array}$ & 8.4 & 8. 8 & 322.4 & 4. 1 & $\begin{array}{r}2.0 \\
(14.3)\end{array}$ \\
\hline 普通の群 & 163 & 3.1 & 17.2 & 55.8 & 13.5 & $\begin{array}{l}5.5 \\
4.9)\end{array}$ & 5.5 & 23.9 & 52.7 & 4.9 & $\begin{array}{r}0 \\
(13.5)\end{array}$ & 10.4 & 38.7 & 35.6 & 1.8 & $\begin{array}{r}0.6 \\
(19.9)\end{array}$ & 5.5 & 30.7 & 38.0 & 11.7 & (14.1) \\
\hline $\begin{array}{l}\text { 不器用な } \\
\text { 群 }\end{array}$ & 44 & 2.3 & 11 & 45.5 & 29.5 & $\begin{array}{r}4.5 \\
(6.8)\end{array}$ & 2.3 & 20.5 & 47.6 & 20.5 & $\begin{array}{r}0 \\
(9.1)\end{array}$ & 4.5 & 43.2 & 34.1 & 9.1 & $\begin{array}{r}0 \\
(9.1)\end{array}$ & 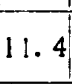 & 15.9 & 54.5 & 9.1 & $\begin{array}{r}0 \\
(9.1)^{\circ}\end{array}$ \\
\hline $\begin{array}{l}\text { 韭常に不 } \\
\text { 器角な群 }\end{array}$ & 5 & & 20.0 & 60.0 & 20.0 & 0 & 0 & & 40.0 & 40.0 & $\begin{array}{r}0 \\
(20.0)\end{array}$ & & 20.0 & 60.0 & 20.0 & 0 & 0 & ) & 40.0 & 60.0 & 0 \\
\hline
\end{tabular}

備考：1. 器用さの段階の各群の数字は，器用さの自己評価による264名中の，それぞれに属する人数 (\%)を示す.

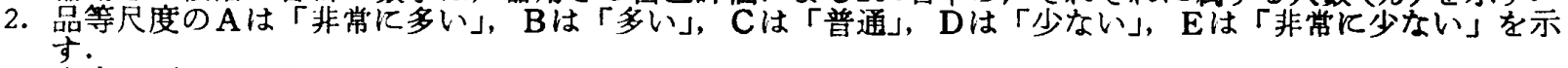

3. 表中の（）は答えのなかった場合を示す. 
表 5 調整力 (器用さ) の優劣と奻稚園との関係 （中学 2 年, 1972年)

\begin{tabular}{|c|c|c|c|c|}
\hline 性 & 器用 - 不器用 & 人 & & \\
\hline 别 & の 别 & 数 & $\begin{array}{c}\text { 有 } \\
(\%)\end{array}$ & $(\%)$ \\
\hline 田 & 器用な群 & 45 & 93 & 7 \\
\hline 力 & 不器用な群 & 45 & 75 & 25 \\
\hline 1 & 器用な 群 & 45 & 87 & 13 \\
\hline & 不器用な器 & 45 & 67 & 33 \\
\hline
\end{tabular}

表 6 調整力（器用さ）の便劣と運動クラブへの参 加との関係

（中学 2 年, 1972年)

\begin{tabular}{|c|c|c|c|c|}
\hline 性 & 器用 - 不器用 & 人 & 参加·不多 & の別 (\%) \\
\hline 别 & の & 数 & 参 加 & 不参加 \\
\hline & 器用な 群 & 45 & 93 & 7 \\
\hline & 不器用な群 & 45 & 33 & 67 \\
\hline 1 & 器用な群 & 45 & 85 & 15 \\
\hline & 不器用な群 & 45 & 15 & 85 \\
\hline
\end{tabular}

すよ5に，器用な群は不器用な群にくらべて，経 験した運動の種類が多く，この傾向は年龄がすす むにつれて著しくなっている。

面接法による第 2 回目の調査によれば，表 5 に 示すよ5に，幼児教育施設に通園した者の率は, 器用な群は不器用な群よりもかなり多い。また， 器用な群では，その $85 \%$ が児童期に，体育的行事 に選手として出場した経験をもち，その40\%はひ とりで 2 種目以上，中には 4 種目にわたって 活躍した者もいた．現在，運動クラブに参加して いる者は, 表 6 に示すよ5に, 器用な群では不器 用な群より著しく多い。

表 7 は，器用な群と不器用な群の健康状態・欠 席状況などを比較して示した第 2 回目の調査結果 である，器用な群が健康にすぐれ，欠席の少ない ことは, 両群間に運動時間や体力で差の生ずる原 因の一つが健康にあることを示するのと言えよ 5 .

上述した，いくつかの結果から，第 1 には器用 な群は不器用な群にくらべて, 一般に, 今日に至 るまでの間に，いずれの発有段階においても，運

表 7 調整力（器用さ）の優劣と健康との関係（中学 2 年, 1972年）

\begin{tabular}{|c|c|c|c|c|c|c|c|c|c|c|c|c|}
\hline \multirow[t]{2}{*}{ 性 } & \multirow{2}{*}{$\begin{array}{l}\text { 器用・不器 } \\
\text { 用 の 別 }\end{array}$} & \multirow{2}{*}{ 人 } & \multicolumn{5}{|c|}{ 疾病䍜患状況 （\%) } & \multicolumn{5}{|c|}{ 学校の欠席状況 （\%) } \\
\hline & & & A & B & $\mathrm{C}$ & D & $\mathrm{E}$ & A & B & $\mathrm{C}$ & $\mathrm{D}$ & $\mathbf{E}$ \\
\hline \multirow{2}{*}{ 男 } & 器用な群 & 45 & 50 & 27 & 13 & 7 & 3 & 40 & 30 & 14 & 13 & 3 \\
\hline & 不器用な群 & 45 & 20 & 33 & 20 & 20 & 7 & 13 & 27 & 27 & 30 & 3 \\
\hline \multirow{2}{*}{ 女 } & 器用な群 & 45 & 20 & 40 & 27 & 10 & 3 & 40 & 40 & 13 & 7 & 0 \\
\hline & 不器用な群 & 45 & 3 & 23 & 27 & 40 & 7 & 20 & 30 & 23 & 20 & 7 \\
\hline
\end{tabular}

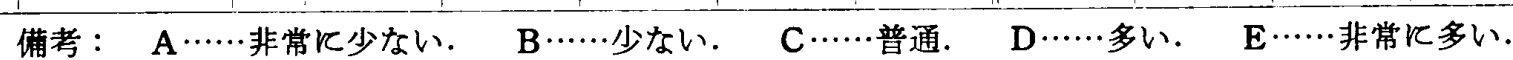

表 8 調整力（器用さ）の優劣と運動仲間の種類との関係（中学 2 年, 1972年）

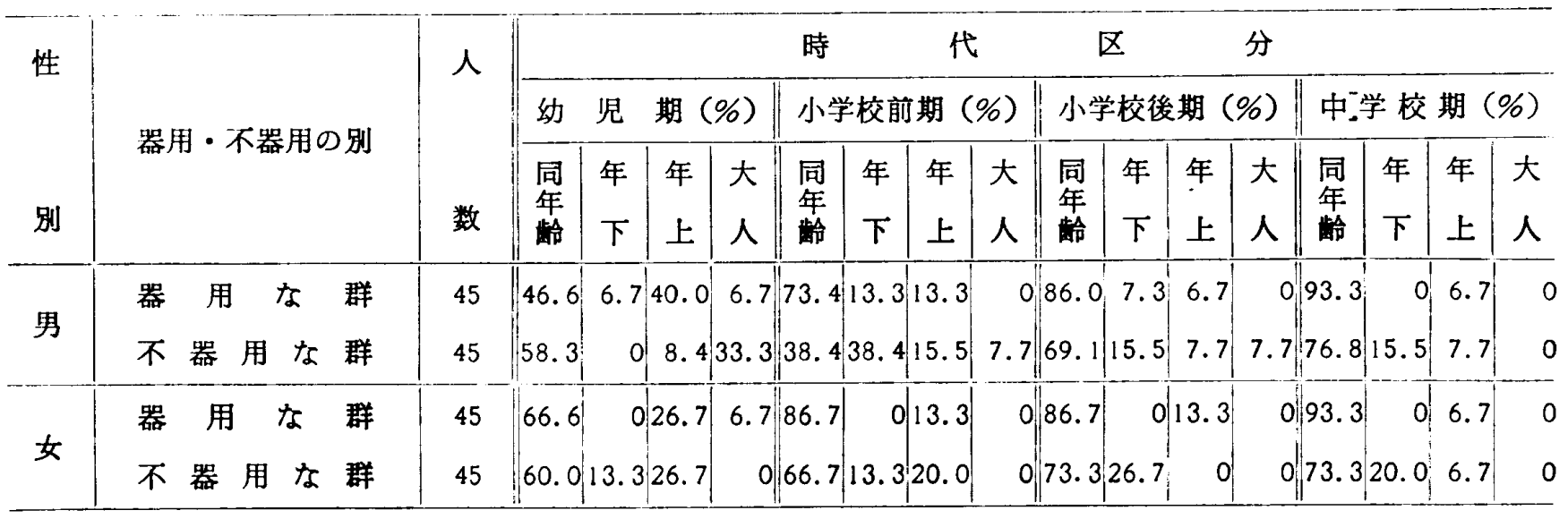


動に使った時間が著しく多いことがわかる。この ことは，一般に器用な群が各種の運動についてよ り効果的な動きを身につけていることを示唆する ものと言えよ5，第 2 には，器用な群は不器用な 群にくらべて，一般に，いずれの発育段階におい ても，経験してきた運動の種類が多いことがわか る。

このように検討してくると，身体資源としての 調整力を十分に開発するには，いずれの発有段階 に抢いても経験する運動の種類を多くし，しかも 効果的な動きを身につけるよ5にしていく必要の 击ることがわかる。

（2）調整力の優劣と遊び仲間，沾親の運動に対

する態度などとの関係について

表 8 は，個人別に面接法によって，主に遊び仲 間の年齢を，発育段階別に調べた第 2 回目の調査 結果を示したものである。この資料から，器用な 群は不器用な群にくらべて，问年齢および年上の 子供と遊んだと答えた者の多いことがわかる。

上述の結果は，问分と同等あるいはより以上の 運動能力を持つ者と遊ぶことが調整力の効果的な
発達に役立つことを示すものと言えよ5．

第 2 回目の調査によると，両親の体育・スポー ツに対する態度には，両群間に著しい差が認めら れた，不器用な群では，両親の約 $40 \%$ が体有・ス ポーツを軽視しているか, 無関心であった。これに 対して，器用な群では，このよ5な態度を示した 両親は約 $5 \%$ にすぎなかった。このことは，体有 ・スポーツに対する両親の態度が子供の調整力の 発達に影響を及ぽすことを示すものと言えよう。

\section{4. 調整力の優劣と運動環境との関係}

表 9 は，器用な群之不器用な群について，これ までに住んできた家に庭があったかど5かを面接 法によって調べた第 2 回目の調查結果である.

なお，幼児教育施設に通園することは，先に述 べたよ5に，運動時間や運動の種類を多くする物 的環境に恵まれることでああると言える。これら の資料は，器用な群の中に庭を積極的に利用して 遊んだと答えた者が多かったことからもわかるよ らに，連動をするのに適した物的環境が調整力の 発達に影響する重要な要因の一つになることを示

表 9 調整力（器用さ）の優劣と庭の有無との関係（中学: 2 年，1972年）

\begin{tabular}{|c|c|c|c|c|c|c|c|c|c|c|}
\hline \multirow{2}{*}{ 性別 } & \multirow{2}{*}{ 器用・不器用の別 } & \multirow{2}{*}{ 人数 } & \multicolumn{2}{|c|}{ 幼 児 期 (\%) } & \multicolumn{2}{|c|}{ 小学校前期 $(\%)$} & \multicolumn{2}{|c|}{ 小学校後期(\%) } & \multicolumn{2}{|c|}{ 中学校期 $(\%)$} \\
\hline & & & 有 & 無 & 有 & 無 & 有 & 無 & 有 & 無 \\
\hline \multirow{2}{*}{ 男 } & 器 用な 群 & 45 & 80 & 20 & 94 & 6 & 80 & 20 & 87 & 13 \\
\hline & 不器用な群 & 45 & 64 & 36 & 67 & 33 & 73 & 27 & 67 & 33 \\
\hline \multirow{2}{*}{ 女 } & 器用な 群 & 45 & 93 & 7 & 93 & 7 & 93 & 7 & 93 & 7 \\
\hline & 不器用な群 & 45 & 67 & 33 & 87 & 13 & 93 & 7 & 93 & 7 \\
\hline
\end{tabular}

表10 調整力（器用さ）の優劣と家族の運動技能水準・作業技能水準との関係（中学 2 年, 1972年）

\begin{tabular}{|c|c|c|c|c|c|c|c|c|c|c|c|c|c|c|c|c|c|c|c|c|c|c|c|c|c|c|}
\hline \multirow{3}{*}{$\begin{array}{l}\text { 器用 - 不器用 } \\
\text { の 別 }\end{array}$} & \multirow{3}{*}{ 人 } & \multicolumn{25}{|c|}{ 家族の運動技能水準・作業技能水準 } \\
\hline & & \multicolumn{2}{|c|}{ 兄 } & \multicolumn{3}{|c|}{ 弟 \% } & \multicolumn{5}{|c|}{ 父 } & \multicolumn{3}{|c|}{ 母 } & \multicolumn{2}{|l|}{ 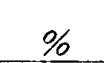 } & \multicolumn{2}{|c|}{ 祖 } & \multicolumn{3}{|c|}{ 父 \% } & \multicolumn{2}{|c|}{ 祖 } & \multicolumn{3}{|c|}{ 母 \% } \\
\hline & & $\mathbf{A}$ & $1-$ & C & D & $\mathrm{E}$ & A & $\mathrm{B}$ & C & D & -1 & A & B & 10 & D & 2 & A & 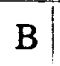 & 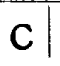 & $\mathrm{D}$ & $\mathbf{E}$ & A & 8 & & $\mathrm{D}$ & 12 \\
\hline 器用な 群 & 90 & 17 & 53 & 20 & 8 & 2 & 27 & 34 & 29 & 8 & 2 & 22 & 31 & 37 & 8 & 2 & 14 & 36 & 36 & 7 & 7 & 6 & 33 & 42 & 12 & \\
\hline 不器 用な & 90 & 0 & 17 & 36 & 40 & 7 & 0 & 17 & 36 & $40^{\prime}$ & 7 & 4 & & 31 & $5 !$ & 10 & 6 & 19 & 50 & 10 & 15 & 3 & 12 & 41 & 41 & \\
\hline
\end{tabular}

備考：1， A・B・C・D・Eは，家族の運動技能・作業技能水準などをもとにした調整力の品等段階を示す. Aは「非常にすくれている」，Bは「すぐれている」，Cは「普通」，Dは「务っている」，Eは「非常に劣 っている」を示す.

2. 調查対象は器用・不器用いずれの群も男女90名であるが，家族の区分別の調查人員はそれぞれ異なる。 
ものと言えよ5。

5. 調整力の優劣と素質，学力などとの関係 表10は，第 2 回目の調査において，器用な群と 不器用な群との間には，その素質に相違があるか を探る手がかりを得よ 5 と，家族の運動技能およ び作業技能の水準を質問紙によって調べた結果を まとめたものである。この資料から，器用な群の 家族が，いずれの場合にも，一般にすぐれている ことがわかる．家族の運動技能，作業技能などの 水準が器用さの一つの指標になり，しかもそれら の技能が各生徒の器用さの素質る知る手がかりに なるとすると，両群間には，一般に，調整力の素 質に関して差があるとみられる。 また，器用な群 は不器用な群にくらへてて家族の運動技能、作業技 能などの水準が高いことは，器用な群が調整力の 発達に有効な剌激が得られるよ5な人的環境に恵 まれていることを示すものと言えよ5。

表11 調整力（器用さ）の優劣と知的能力との関係 （中学 2 年, 1972年)

\begin{tabular}{|c|c|c|c|c|}
\hline 性 & 器用・不器 & 人 & 知 & 学 \\
\hline 別 & 用 の 別 & 数 & $M(S \cdot D)$ & $M(S \cdot D)$ \\
\hline \multirow{2}{*}{ 男 } & 器用な群 & 45 & $51.17(8.07)$ & $51.56(8.22)$ \\
\hline & 不器用な群 & 45 & $48.35(9.84)$ & $47.56(11.98)$ \\
\hline \multirow{2}{*}{ 女 } & 器用な群 & 45 & $50.75(6.75)$ & $56.90(4.40)$ \\
\hline & 不器用な群 & 45 & $43.50(7.98)$ & $45.50(10.70)$ \\
\hline
\end{tabular}

表11は調整力の優劣と知能および学力との関係 を示す第 2 [问目の調查結果である。器用な群は不 器用な群にくらべて知能・学力ともにすぐれてい る傾向が認められることから，知的能力も調整力 の発達に影響を及ぼす一つの要因になっているこ とがわかる。

\section{III. 結論としての示喛}

結果とその考察をもとにすると，身体資源ある いは行動体力の一つの要因としての調整力のとら え方やその開発法に関連して，次に列挙するいく つかの結論的な示唆を引き出すことが許されよ 5 .
1. 身体資源としての調整力のとらえ方に関す る示唆

(1) 身体資源（行動体力）のサイバネティック ス系の要因としての調整力を「運動技術の学 習能力」としてとらえることは，体育実践の 立場から適切であるとみられる。

(2) 実際に発現する調整力の優劣は，エネルギ 一系の行動体力要因としての筋力，パワー, 持久力などによっても大きく影響される。

2. 身体資源の一つとしての調整力の 開発法に 関する示唆

(1) 身体資源（行動体力）の一つの要因として の調整力を効果的に十分に開発するために， 幼児期，览童期，青年期を通して，経験させ る運動の種類を多くし，乙かも効果的な動き を身につけさせるよ5にしていくことが必要 である。

したがって，現代および末来の生活・生存 の場に十分に適応していけるよ5な調整力が 高められるようにするには，人間の生活・生 存に役立つ基礎的動きを体系的にとらえ，こ れらが計画的に身につけられるよ5に，発育 段階に即した体有運動を体系的に準備する必 要がある。

(2) 身体資源としての調整力を十分に開発する には，運動環境を物的にも，人的にも，発有 即階に即して整える必要がある。

本研究の調査は，千葉県木更津市立第一中学 校, 岩根中学校, 柏市立柏第二中学校, 袖ケ浦町 立平川中学校などの協力によって行った。協力い ただいた先生，生徒，父兄などに感謝を捧げる。

\section{参考文献}

1）猪飼道夫ほか，「行動体力」猪飼夫道ほか(編)，体 育科学亭典, 第一法規, 1970, pp. 104 12.

2）猪飼道夫「「サイバネティッスからみた体力」猪飼 道夫ほか(編)，体育科学亭典，第一法規，1970，pp. $107 \sim 108$.

3）小野三周ほか，「調整力を知る方法に関する研究」

体育科学, $2: 300 \sim 308,1974$. 
4）金原勇，「調整力」猪飼道夫，金原勇ほか(編), 程目別現代トレーニンク法, 大修館書店，1968，pp. $41 \sim 42$.

5）金原 勇，「私は調整力をこう考える」体育の科 学, $21 \sim 1: 22 \sim 24,1972$.

6）石河利寛，「調整力」体育の科学，23〜9：618〜
$21,1973$.

7）名取礼二ほか，「運動の習熟機構に関する研究」東 京教育大学スポーツ研究所報, $1: 1 \sim 25$.

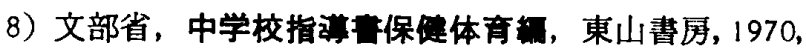
p. 16. 